\title{
Human Ammonia Emission Rates under Various Indoor Environmental Conditions
}

\author{
Li, Mengze; Weschler, Charles J.; Beko, Gabriel; Wargocki, Pawel; Lucic, Gregor; Williams, Jonathan
}

Published in:

Environmental Science and Technology

Link to article, DOI:

10.1021/acs.est.0c00094

Publication date:

2020

Document Version

Publisher's PDF, also known as Version of record

Link back to DTU Orbit

Citation (APA):

Li, M., Weschler, C. J., Beko, G., Wargocki, P., Lucic, G., \& Williams, J. (2020). Human Ammonia Emission Rates under Various Indoor Environmental Conditions. Environmental Science and Technology, 54(9), 54195428. https://doi.org/10.1021/acs.est.0c00094

\section{General rights}

Copyright and moral rights for the publications made accessible in the public portal are retained by the authors and/or other copyright owners and it is a condition of accessing publications that users recognise and abide by the legal requirements associated with these rights.

- Users may download and print one copy of any publication from the public portal for the purpose of private study or research.

- You may not further distribute the material or use it for any profit-making activity or commercial gain

- You may freely distribute the URL identifying the publication in the public portal 


\title{
Human Ammonia Emission Rates under Various Indoor Environmental Conditions
}

\author{
Mengze Li, Charles J. Weschler,* Gabriel Bekö, Pawel Wargocki, Gregor Lucic, and Jonathan Williams* \\ Cite This: Environ. Sci. Technol. 2020, 54, 5419-5428 \\ Read Online
}

ABSTRACT: Ammonia $\left(\mathrm{NH}_{3}\right)$ is typically present at higher concentrations in indoor air $(\sim 10-70 \mathrm{ppb})$ than in outdoor air $(\sim 50 \mathrm{ppt}$ to $5 \mathrm{ppb})$. It is the dominant neutralizer of acidic species in indoor environments, strongly influencing the partitioning of gaseous acidic and basic species to aerosols, surface films, and bulk water. We have measured $\mathrm{NH}_{3}$ emissions from humans in an environmentally controlled chamber. A series of experiments, each with four volunteers, quantified $\mathrm{NH}_{3}$ emissions as a function of temperature $\left(25.1-32.6{ }^{\circ} \mathrm{C}\right.$ ), clothing (longsleeved shirts/pants or T-shirts/shorts), age (teenagers, adults, and seniors), relative humidity (low or high), and ozone ( $<2 \mathrm{ppb}$ or $\sim 35 \mathrm{ppb}$ ). Higher temperature and more skin exposure ( $\mathrm{T}$-shirts/shorts) significantly increased

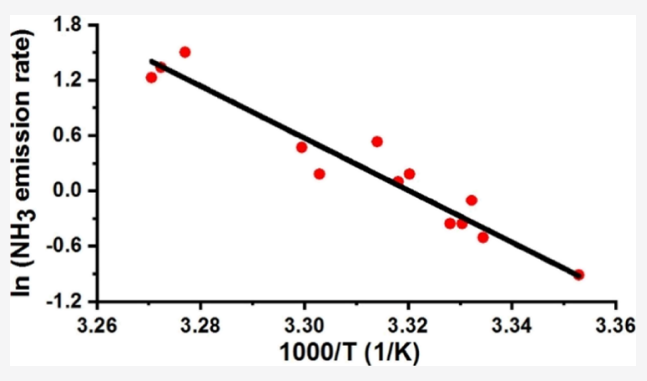
emission rates. For adults and seniors (long clothing), $\mathrm{NH}_{3}$ emissions are estimated to be $0.4 \mathrm{mg} \mathrm{h}^{-1}$ person $^{-1}$ at $25^{\circ} \mathrm{C} 0.8 \mathrm{mg} \mathrm{h}^{-1}$ person ${ }^{-1}$ at $27^{\circ} \mathrm{C}$, and $1.4 \mathrm{mg} \mathrm{h}^{-1}$ person ${ }^{-1}$ at $29^{\circ} \mathrm{C}$, based on the temperature relationship observed in this study. Human $\mathrm{NH}_{3}$ emissions are sufficient to neutralize the acidifying impacts of human $\mathrm{CO}_{2}$ emissions. Results from this study can be used to more accurately model indoor and inner-city outdoor $\mathrm{NH}_{3}$ concentrations and associated chemistry.

\section{INTRODUCTION}

Ammonia $\left(\mathrm{NH}_{3}\right)$ is a colorless gas with a strong, pungent odor, whose detection threshold is $1.5 \mathrm{ppm} .{ }^{1}$ The threshold for sensory irritation in eyes and airways is in the range of 20-50 ppm. ${ }^{2}$ It is typically measured at mixing ratios of 50 parts per trillion (ppt) to 5 parts per billion (ppb) in outdoor air, where sources include forest fires, livestock, decay of organic matter, motor vehicle exhaust, and industrial emissions. ${ }^{3-6}$ In the aqueous phase, $\mathrm{NH}_{3}$ is in equilibrium with the ammonium ion $\left(\mathrm{NH}_{4}^{+}\right)$, which is an important nutrient for plants and animals. In both outdoor and indoor environments, $\mathrm{NH}_{3}$ is the dominant basic species. It partially neutralizes the impact of $\mathrm{CO}_{2}$ and other acidic gases on bulk water, aqueous aerosols, and aqueous surface films. ${ }^{8}$ Through several multiphase reactions, $\mathrm{NH}_{3}$ contributes significantly to $\mathrm{PM}_{2.5}$ formation; ${ }^{9-12}$ it also impacts partitioning of gaseous acidic and basic species to aqueous aerosols, aqueous surface films, and bulk water; ${ }^{13,14}$ thus, it has a substantial impact on air quality. In nonindustrial environments, chemesthesis is its dominating health effect, ${ }^{2}$ and minor neurophysiological effects are expected. ${ }^{15}$ Higher $\mathrm{NH}_{3}$ concentrations are associated with adverse health effects including irritation of eyes, nose, and skin; headaches; asthma; and other respiratory problems. ${ }^{16,17}$ $\mathrm{NH}_{3}$ is also toxic to the brain, perturbing the ability of glial cells to remove potassium. ${ }^{18}$ The U.S. Occupational Safety and Health Administration and British Health and Safety Executive have set limits on $\mathrm{NH}_{3}$ exposure of 25 parts per million (ppm) over an $8 \mathrm{~h}$ period and $35 \mathrm{ppm}$ over a 15 min period. ${ }^{19,20}$

Concentrations of $\mathrm{NH}_{3}$ tend to be significantly higher in indoor air than in outdoor air, often by a factor of ten or more. ${ }^{8,21-29} \mathrm{NH}_{3}$ has numerous indoor sources, including smoking, cooking, cleaning, ${ }^{29}$ concrete, $^{30}$ and human emissions. ${ }^{31-40}$ Given the increased use of low-polluting materials and the decreased use of $\mathrm{NH}_{3}$-containing cleaning products, building occupants can become the dominant source of indoor $\mathrm{NH}_{3}$. With decreasing air change rates, driven by energy considerations, human $\mathrm{NH}_{3}$ emissions result in higher indoor $\mathrm{NH}_{3}$ concentrations for otherwise identical conditions. Previous studies reporting indoor $\mathrm{NH}_{3}$ concentrations have been comprehensively summarized by Ampollini et al. ${ }^{29}$ (Table S1, therein) and Nazaroff and Weschler ${ }^{8}$ (Table 6, therein). A number of the larger studies warrant specific mention. In a pioneering study, $\mathrm{Li}$ and Harrison ${ }^{21}$ measured indoor and co-occurring outdoor $\mathrm{NH}_{3}$ at 13 University of Essex buildings. Indoor concentrations were in the range of 10-69 ppb with an average of $29 \mathrm{ppb}$, ten times higher than average outdoor concentrations. Liang and Waldman ${ }^{23}$ measured summer-time indoor $\mathrm{NH}_{3}$ concentrations in a daycare, a nursing home, and a home for the elderly in New Jersey. The mean gas-phase $\mathrm{NH}_{3}$ concentration in the day-care center was $61 \mathrm{ppb}$; in the nursing home, it was $56 \mathrm{ppb}$; and in the home for elderly, it was $31 \mathrm{ppb}$. The indoor-to-outdoor

Received: January 7, 2020

Revised: March 31, 2020

Accepted: April 1, 2020

Published: April 1, 2020

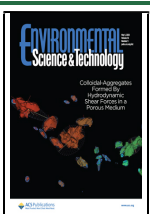


ratio in the nursing home (geometric mean 10.6) was the highest among the three sites. Suh et al. ${ }^{24}$ surveyed acidic aerosols and $\mathrm{NH}_{3}$ at 24 homes with children in Uniontown, PA. The median $\mathrm{NH}_{3}$ concentrations outdoor, indoor, and personal (collected on the shoulder strap of backpacks) were $0.3,22$, and $56 \mathrm{ppb}$, respectively. In a subsequent study at 47 homes in State College, PA, Suh et al. ${ }^{27}$ measured median indoor $\mathrm{NH}_{3}$ concentrations of $20 \mathrm{ppb}$. Spengler et al. ${ }^{26}$ reported mean $\mathrm{NH}_{3}$ concentrations from 10 homes in Albuquerque, New Mexico, each with 3-4 occupants, in the range of $14-30 \mathrm{ppb}$ with an average of $20 \mathrm{ppb}$. Leaderer et al. ${ }^{28}$ quantified indoor $\mathrm{NH}_{3}$ concentrations in 58 homes in Virginia and Connecticut during summer and a further 223 homes during winter. Indoor summer $\mathrm{NH}_{3}$ levels averaged 32 $\mathrm{ppb}$ in homes with air conditioning and $28 \mathrm{ppb}$ in homes without air conditioning. Indoor winter $\mathrm{NH}_{3}$ levels averaged $44 \mathrm{ppb}$ in homes with kerosene heaters and $38 \mathrm{ppb}$ in homes without kerosene heaters.

Gas-phase $\mathrm{NH}_{3}$ is removed by indoor surfaces, and indoor surfaces are large reservoirs for $\mathrm{NH}_{3}$. This has been recently demonstrated by venting experiments ${ }^{29}$ conducted in a test house whose building materials were not a major source of ammonia. In these experiments, $\mathrm{NH}_{3}$ concentrations fell when windows were opened but rebounded relatively quickly when the windows were closed.

Ammonia in the human body stems primarily from the bacterial breakdown of proteins within cells and the intestine. It is transported by blood to the liver where it is converted to urea and ultimately washed out in urine. Ammonia remaining in the blood can diffuse through the skin or be emitted in sweat ${ }^{32,37}$ or breath. ${ }^{33,35}$ Most research to date has focused on breath $\mathrm{NH}_{3}$ concentration and its link to age, gender, and hepatic disease. ${ }^{31,33-38}$ Surprisingly, little research has addressed dermal $\mathrm{NH}_{3}$ emissions from humans, despite the fact that dermal emissions tend to be substantially higher than breath emissions. ${ }^{37,39,40}$

Considering that humans spend more than $90 \%$ of their life in indoor environments, ${ }^{41}$ coupled with the strong impact that $\mathrm{NH}_{3}$ has on indoor acid-base processes, ${ }^{8}$ it is important to understand the determinants of indoor $\mathrm{NH}_{3}$ concentrations, especially the fraction coming from humans themselves. This includes characterizing how human $\mathrm{NH}_{3}$ emission rates vary as a function of typical indoor air variables such as temperature, humidity, and ozone, as well as personal factors such as age and clothing coverage. In this study, we have assessed human $\mathrm{NH}_{3}$ emission rates (from whole body, from skin, and from breath) as a function of temperature, clothing (skin coverage), age, relative humidity, and ozone levels. Real-time measurements were made with five groups, each consisting of four healthy individuals, and housed within a controlled climate chamber, using a state-of-the-science cavity ring-down spectrometer (CRDS). This study is part of the Indoor Chemical Human Emissions and Reactivity (ICHEAR) project.

\section{MATERIALS AND METHODS}

Experimental Design and Chamber Description. Details regarding experimental design and measurement methods used in the ICHEAR project are described elsewhere. $^{42}$ In brief, 18 unique experiments allowed us to investigate the influence of temperature, humidity, clothing, age, and ozone on human emission of $\mathrm{NH}_{3}$. During each experiment, four volunteers were seated in one of two adjacent
$22.5 \mathrm{~m}^{3}$ stainless-steel climate chambers ${ }^{43}$ at the Technical University of Denmark. The original intent was to have chamber temperatures in the range of either $21{ }^{\circ} \mathrm{C}$ or $27^{\circ} \mathrm{C}$. However, we were forced to conduct the experiments at higher temperatures $\left(25.1-32.6{ }^{\circ} \mathrm{C}\right)$ given mild outdoor temperatures, coupled with four occupants in a small volume and the need to avoid recirculation of chamber air. The relative humidity was either low $(\sim 25 \%)$ or high $(\sim 65 \%)$; to maintain the higher relative humidity, a steam humidifier in the HVAC system cycled on and off. Ozone was either absent $(<2 \mathrm{ppb})$ or present ( $35 \mathrm{ppb}$ in occupied chamber). Each day, the subjects wore a brand-new set of standard clothing, prewashed at $40{ }^{\circ} \mathrm{C}$ with fragrance-free detergent (Tex Liquid Enzyme 758, Novadan, Kolding, Denmark), tumble-dried, and packed in individual zip-lock bags using nitrile gloves. The clothing was either "short" (polyester shorts, cotton t-shirt, and ankle socks) or "long" (cotton sweatpants, long-sleeve shirts, and calf socks). The clothing was put on about $30 \mathrm{~min}$ prior to the onset of exposure and taken off just after exposure ceased. No shoes were allowed.

The chamber was continuously ventilated with $100 \%$ outdoor air at an air change rate of $3.2 \mathrm{~h}^{-1}$. The incoming air was filtered with a combination of particulate filters and high efficiency molecular filters (activated carbon), resulting in "ozone-free" supply air. Efficient air mixing was ensured by operating two mixing fans in the chamber, both pointing away from the subjects and toward the chamber walls. In order to assess dermally emitted and exhaled $\mathrm{NH}_{3}$ separately, additional experiments were performed. The subjects sat in one chamber and exhaled the air into the adjacent chamber through breathing masks (Sperian ValuAir Plus 6100V series RP155) attached to Teleflex medical tubes with lengths between 2 and $3 \mathrm{~m}$; small fans at the end of the tubes operated at a low speed to insure that the exhaled air was delivered to the other chamber. $^{42}$

Five groups, each consisting of four nonsmoking Caucasian volunteers without asthma, allergies, or any chronic disease, were recruited to participate in the study. Three groups (A1, $\mathrm{A} 2$, and A3) consisted of young adults with an average age of 25.1 years (range 19-30) and an average BMI of 21.6 (range 20-23.9). One group consisted of teenagers (T4) with an average age of 13.8 years (range 13-15) and BMI of 19.5 (range 19.1-20.4), and the one consisted of seniors (S5) with an average age of 70.5 years (range 68-72) and BMI of 25.6 (range 22.5-28.1).

The volunteers were instructed not to drink alcohol or eat spicy food, garlic, chewing gum, or mint drops, one day prior to and during the days of the experiments. They were asked to keep a consistent diet and mode of transport to the lab in the morning. They received and were asked to only use the provided paraben-, perfume-, and colorant-free liquid soap and shampoo (Neutral, Unilever Denmark, Copenhagen, Denmark) as well as toothpaste (Zendium Classic, Unilever). They were asked to shower the evening prior to each experiment and to wash underwear with the perfume-free laundry detergent that was provided.

The volunteers were in the chamber either (i) $3 \mathrm{~h}$ in the morning without ozone followed by $2.5 \mathrm{~h}$ in the afternoon with ozone or (ii) only $3 \mathrm{~h}$ in the morning with ozone. During the morning/afternoon configuration of the experiment, there was a lunch break of $10 \mathrm{~min}$, and ozone generation started $10 \mathrm{~min}$ after the subjects returned to the chamber. Identical lunches 
Table 1. Measured Human $\mathrm{NH}_{3}$ Emission Rates Grouped According to the Various Factors That Were Evaluated ${ }^{a, b}$

\begin{tabular}{|c|c|c|c|c|c|c|c|}
\hline \multirow[b]{2}{*}{ factor } & \multirow[b]{2}{*}{ conditions } & \multicolumn{2}{|c|}{$\begin{array}{c}\text { emission rate }{ }^{c} \\
\left(\mathrm{mg} \mathrm{h}^{-1} \text { person }^{-1}\right)\end{array}$} & \multicolumn{2}{|c|}{$\begin{array}{l}\text { mean chamber temperature } \\
\left({ }^{\circ} \mathrm{C}\right)\end{array}$} & \multirow[b]{2}{*}{ group } & \multirow[b]{2}{*}{ date } \\
\hline & & morning & afternoon & morning & afternoon & & \\
\hline \multirow[t]{4}{*}{ reproducibility } & long, moderate $\mathrm{T} /$ low $\mathrm{RH}, \mathrm{O}_{3}$ afternoon & $1.2^{d}$ & $>1.1$ & 26.6 & 27.9 & $\mathrm{~T} 4$ & 0517 \\
\hline & long, moderate $\mathrm{T} /$ low $\mathrm{RH}, \mathrm{O}_{3}$ afternoon & $1.5^{\mathrm{d}}$ & $>1.5$ & 28.0 & 29.6 & $\mathrm{~T} 4$ & 0519 \\
\hline & long, moderate $\mathrm{T} /$ high $\mathrm{RH}$, no $\mathrm{O}_{3}$ & $1.2^{d}$ & & 28.2 & & A1 & 0423 \\
\hline & long, moderate $\mathrm{T} /$ high $\mathrm{RH}$, no $\mathrm{O}_{3}$ & $1.2^{\mathrm{d}}$ & & 29.7 & & A1 & 0425 \\
\hline \multirow[t]{4}{*}{ temperature } & moderate $\mathrm{T}$ (long, low $\mathrm{RH}, \mathrm{O}_{3}$ afternoon) & 1.1 & 1.6 & 28.2 & 29.9 & A1 & 0426 \\
\hline & high $\mathrm{T}$ (long, low $\mathrm{RH}, \mathrm{O}_{3}$ afternoon) & $3.7^{\mathrm{d}}$ & $4.4^{d}$ & 32.4 & 32.0 & A1 & 0429 \\
\hline & moderate $\mathrm{T}$ (long, high $\mathrm{RH}$, no $\mathrm{O}_{3}$ ) & $1.2^{d}$ & & 28.2 & & $\mathrm{~A} 1$ & 0423 \\
\hline & high $\mathrm{T}$ (long, high $\mathrm{RH}, \mathrm{O}_{3}$ afternoon) & $3.3^{d}$ & 4.5 & 32.6 & 32.4 & A1 & 0430 \\
\hline \multirow[t]{4}{*}{ clothing } & long (moderate $\mathrm{T} /$ low $\mathrm{RH}, \mathrm{O}_{3}$ afternoon) & 0.35 & 0.9 & 25.1 & 27.0 & A2 & 0415 \\
\hline & short (moderate $\mathrm{T} /$ low $\mathrm{RH}, \mathrm{O}_{3}$ afternoon) & 0.57 & 0.9 & 25.6 & 27.6 & $\mathrm{~A} 2$ & 0416 \\
\hline & long (high $\mathrm{T} /$ high $\mathrm{RH}, \mathrm{O}_{3}$ afternoon) & $3.3^{d}$ & 4.5 & 32.6 & 32.4 & A1 & 0430 \\
\hline & short (high $\mathrm{T} /$ high $\mathrm{RH}$, no $\mathrm{O}_{3}$ ) & 5.2 & & 32.6 & & A1 & 0424 \\
\hline \multirow[t]{6}{*}{ age } & long, moderate $\mathrm{T} /$ low $\mathrm{RH}, \mathrm{O}_{3}$ afternoon & 0.35 & 0.9 & 25.1 & 27.0 & A2 & 0415 \\
\hline & long, moderate $\mathrm{T} /$ low $\mathrm{RH}, \mathrm{O}_{3}$ afternoon & 1.1 & 1.6 & 28.2 & 29.9 & A1 & 0426 \\
\hline & long, moderate $\mathrm{T} /$ low $\mathrm{RH}, \mathrm{O}_{3}$ afternoon & $0.60^{d}$ & $>0.6$ & 27.1 & 28.4 & A3 & 0508 \\
\hline & long, moderate $\mathrm{T} /$ low $\mathrm{RH}, \mathrm{O}_{3}$ afternoon & $1.2^{d}$ & $>1.1$ & 26.6 & 27.9 & $\mathrm{~T} 4$ & 0517 \\
\hline & long, moderate $\mathrm{T} /$ low $\mathrm{RH}, \mathrm{O}_{3}$ afternoon & $1.5^{d}$ & $>1.5$ & 28.0 & 29.6 & $\mathrm{~T} 4$ & 0519 \\
\hline & long, moderate $\mathrm{T} /$ low $\mathrm{RH}, \mathrm{O}_{3}$ afternoon & $0.74^{d}$ & 1.7 & 27.1 & 28.7 & S5 & 0515 \\
\hline \multirow[t]{4}{*}{ humidity } & low $\mathrm{RH}$ (high $\mathrm{T}$, long, $\mathrm{O}_{3}$ afternoon) & $3.7^{d}$ & $4.4^{d}$ & 32.4 & 32.0 & A1 & 0429 \\
\hline & high $\mathrm{RH}$ (high $\mathrm{T}$, long, $\mathrm{O}_{3}$ afternoon) & $3.3^{d}$ & 4.5 & 32.6 & 32.4 & A1 & 0430 \\
\hline & low $\mathrm{RH}$ (moderate $\mathrm{T}$, long, $\mathrm{O}_{3}$ afternoon) & 1.1 & 1.6 & 28.2 & 29.9 & A1 & 0426 \\
\hline & high $\mathrm{RH}$ (moderate $\mathrm{T}$, long, no $\mathrm{O}_{3}$ ) & $1.2^{d}$ & & 28.2 & & A1 & 0423 \\
\hline \multirow[t]{5}{*}{ ozone } & long, moderate $\mathrm{T} /$ low $\mathrm{RH}, \mathrm{O}_{3}$ afternoon & $1.2^{d}$ & $>1.1$ & 26.6 & 27.9 & $\mathrm{~T} 4$ & 0517 \\
\hline & long, moderate $\mathrm{T} /$ low $\mathrm{RH}, \mathrm{O}_{3}$ morning & $1.0^{d}$ & & 27.3 & & $\mathrm{~T} 4$ & 0518 \\
\hline & long, moderate $\mathrm{T} /$ low $\mathrm{RH}, \mathrm{O}_{3}$ afternoon & $1.5^{d}$ & $>1.5$ & 28.0 & 29.6 & $\mathrm{~T} 4$ & 0519 \\
\hline & long, moderate $\mathrm{T} /$ low $\mathrm{RH}, \mathrm{O}_{3}$ morning & $0.66^{d}$ & & 27.3 & & S5 & 0514 \\
\hline & long, moderate $\mathrm{T} /$ low $\mathrm{RH}, \mathrm{O}_{3}$ afternoon & $0.74^{d}$ & 1.7 & 27.1 & & S5 & 0515 \\
\hline \multirow[t]{2}{*}{ dermal only } & high $\mathrm{T} /$ high $\mathrm{RH}$, short, $\mathrm{O}_{3}$ afternoon & 4.4 & 6.8 & 31.0 & 31.0 & A3 & 0502 \\
\hline & moderate $\mathrm{T} /$ low $\mathrm{RH}$, short, $\mathrm{O}_{3}$ afternoon & 0.92 & $>0.8$ & 27.9 & 29.3 & A3 & 0507 \\
\hline \multirow[t]{2}{*}{ breath only } & high $\mathrm{T} /$ high $\mathrm{RH}$, short, $\mathrm{O}_{3}$ afternoon & $>0.027$ & & 32.5 & & $\mathrm{~A} 3$ & 0503 \\
\hline & moderate $\mathrm{T} /$ low $\mathrm{RH}$, long, $\mathrm{O}_{3}$ morning & $>0.017$ & & 26.1 & & $\mathrm{~A} 3$ & 0506 \\
\hline
\end{tabular}

${ }^{a_{\text {There }}}$ are 18 unique experiments; some experiments appear in more than one "factor" grouping ${ }^{b}$ Long: long sleeve shirt and long pants; short: $\mathrm{t}$ shirt and shorts; moderate $\mathrm{T}$ : mean $27.7^{\circ} \mathrm{C}$, range $25.1-29.9^{\circ} \mathrm{C}$; high $\mathrm{T}$ : mean $32.4^{\circ} \mathrm{C}$, range $32.0-32.6{ }^{\circ} \mathrm{C}$; low $\mathrm{RH}$ : range $22.1-36.8 \%$; and high RH: range 61.6-62.9\%. Groups A1, A2, and A3: adults (age 19-30); Group T4: teenagers (age 13-15); and Group S5: seniors (age 68-72). "Values with ">" should be viewed as lower limits for emission rates and have been used when the steady state could not be reliably estimated. ${ }^{d}$ Experiment reached the steady state.

consisting of bread, butter, and sliced cheese were provided on all experimental days with an afternoon component.

Instrumentation. To measure real-time changes in the concentration of gas-phase $\mathrm{NH}_{3}$ inside the chambers, we utilized a Picarro G2103 analyzer (Picarro Inc., Santa Clara, CA). The instrument is a CRDS that uses a near infra-red laser source to make time-based absorption measurements of $\mathrm{NH}_{3}$ (as well as $\mathrm{CO}_{2}$ and $\mathrm{H}_{2} \mathrm{O}$ ) in air, with a high time-resolution of $1 \mathrm{~Hz}$. As reported by Picarro Inc., this specific model had a precision of $\pm 0.15 \mathrm{ppb}$ for $\mathrm{NH}_{3}$ with an instrument zero drift < $\pm 0.15 \mathrm{ppb}$ over $72 \mathrm{~h}$ and $< \pm 0.5 \mathrm{ppb}$ over a month (peak-topeak, $50 \mathrm{~min}$ box averages). The absorptivity of the analyzer was calibrated at Picarro's factory against a "Golden” Analyzer, whose calibration was validated by the National Physical Laboratory (United Kingdom) using gravimetric standards and reported to be within $1 \%$ of the standard, ${ }^{44}$ with an overall uncertainty of $2 \%$. The manufacturer calibration for $\mathrm{NH}_{3}$ was used for quantitation in this work. Supporting studies indicate extended CRDS stability ( $0.1 \%$ slope change/year). ${ }^{45}$ The sample handling of the analyzer is composed primarily of stainless steel coated with SilcoNert with a Teflon particulate filter. It was operated at a flowrate of $1.7 \mathrm{~L} / \mathrm{min}$. In this study, we used the instrument "NH3_dry" variable, which corrects for water and reports the dry-mole fraction of $\mathrm{NH}_{3}$. The Picarro G2103 analyzer was placed immediately adjacent to the chamber ceiling exhaust with a Teflon inlet line $(\sim 20 \mathrm{~cm}$ in length) passing into the exhaust duct.

A second CRDS (Picarro G2401 analyzer) was used to measure $\mathrm{CO}_{2}$ in the chamber. It had a 5 min-averaged precision of $7 \mathrm{ppb}$. After the entire experimental campaign, which lasted 7 weeks, the analyzer was calibrated with the standard calibration gas at $\mathrm{CO}_{2}$ levels of 500, 1000, 1500, 2000, and $2500 \mathrm{ppm}$ with the linearity $R^{2}>0.99999$. Details are discussed in Bekö et al. ${ }^{42}$ As $\mathrm{CO}_{2}$ has negligible loss in the chamber, the occupied chamber air change rate was calculated using the decay rate of $\mathrm{CO}_{2}$ after the volunteers had left. The calculated air change rates were confirmed by independent measurements with an Innova 1302 instrument using Freon $134 \mathrm{~A}$ as a tracer gas. The air change rate $\left(3.2 \mathrm{~h}^{-1}\right)$ was stable during the entire campaign.

Human Emission Rate Estimation Methods. Steadystate Method. Under steady-state conditions, the chamber 
surfaces are neither sinks nor sources of $\mathrm{NH}_{3}$; the occupants are the only source, and ventilation is the only sink. Thus, the $\mathrm{NH}_{3}$ emission rate can be calculated as

$$
E=\lambda V\left(C_{\mathrm{ss}}-C_{\mathrm{i}}\right)
$$

where $E$ is the $\mathrm{NH}_{3}$ emission rate $\left(\mathrm{mg} \mathrm{h}^{-1}\right)$ from humans, $\lambda$ is the air change rate $\left(\mathrm{h}^{-1}\right), V$ is the chamber volume $\left(22.5 \mathrm{~m}^{3}\right)$, $C_{\mathrm{ss}}\left(\mathrm{mg} \mathrm{m}^{-3}\right)$ is the steady-state $\mathrm{NH}_{3}$ concentration, and $C_{\mathrm{i}}$ $\left(\mathrm{mg} \mathrm{m}^{-3}\right)$ is the $\mathrm{NH}_{3}$ concentration before occupants enter the chamber. Only about half the experiments reached the steady state. When the $\mathrm{NH}_{3}$ concentration did not reach the steady state, we estimated steady-state concentrations using a sigmoidal Boltzmann curve. A more detailed description of how the steady state was estimated is provided in the Supporting Information (estimation of steady-state concentrations, Sigmoidal Boltzmann curve fitting, Figure S1, and Table S1).

Integral Mass-balance Method. This approach ${ }^{46}$ is based on the fact that the total $\mathrm{NH}_{3}$ emitted during the time that the volunteers are in the chamber must equal the total removed by ventilation. Experiments that meet the following criteria can be examined with this method:

1 sources and sinks of $\mathrm{NH}_{3}$ in the chamber do not change, that is, no other sources (e.g., cleaning products and food intake) nor sinks (e.g., chamber door open) interfere with the experiment;

2 measurements continue until the $\mathrm{NH}_{3}$ concentration returns to its value prior to the volunteers entering the chamber;

3 the air change rate is constant throughout the period

The data that best satisfied these criteria were those from the experiments on May 14 and May 18 (see Table 1). Emission rates calculated with the integral mass balance method are compared with those estimated by the steady-state method in the Results and Discussion section.

\section{RESULTS AND DISCUSSION}

Measured Emission Rates. Table 1 summarizes human $\mathrm{NH}_{3}$ emission rates, calculated using the steady-state method (see Materials and Methods), for different experimental conditions. The experiments are grouped according to factors that were targeted by a given set of experiments; some experiments were used to target more than one factor. The morning emission rates are based on measurements made between 9:30, when the volunteers entered the chamber, and $12: 30$, when the volunteers exited the chamber. On some days, the volunteers had a light lunch and re-entered the chamber for afternoon measurements ending at 15:15. The light lunch appears to have influenced $\mathrm{NH}_{3}$ emission rates, as further discussed in the Ozone subsection. Among the morning emission rates, the highest adult value was $5.2 \mathrm{mg} \mathrm{h}^{-1}$ person $^{-1}$ observed for adult group A1 wearing short clothing ( $t$-shirts and shorts) at $32.6^{\circ} \mathrm{C}$ and high $\mathrm{RH}$. The lowest adult emission was $0.35 \mathrm{mg} \mathrm{h}^{-1}$ person $^{-1}$ for adult group A2 wearing long clothing at $25.1{ }^{\circ} \mathrm{C}$ and low $\mathrm{RH}$; for the same clothing and relative humidity condition, the adult group $\mathrm{A} 3$ had an emission rate of $0.60 \mathrm{mg} \mathrm{h}^{-1}$ person ${ }^{-1}$ at $27.1^{\circ} \mathrm{C}$ (May 8), and the adult group $\mathrm{A} 1 \mathrm{had}$ an emission rate of $1.1 \mathrm{mg} \mathrm{h}^{-1}$ person $^{-1}$ at $28.2{ }^{\circ} \mathrm{C}$ (April 26). As a check on the results obtained with the steady-state method, the emission rates in Table 1 for May 14 and May 18 (0.66 and $1.0 \mathrm{mg} \mathrm{h}^{-1}$ person $^{-1}$ ) were compared with those calculated using the integral mass-balance method for the same dates ( 0.74 and 1.2 $\mathrm{mg} \mathrm{h}^{-1}$ person $\left.^{-1}\right)$. Hence, the relative error between the two approaches is $12 \%$ for the May 14 experiment and $20 \%$ for the May 18 experiment.

Reproducibility. As shown in Figure S2, we conducted a pair of replicate experiments for teenagers (Group T4) and a pair of replicate experiments for adults (Group A1). The replicate emission rates were 1.2 and $1.5 \mathrm{mg} \mathrm{h}^{-1}$ person $^{-1}$ for the teenage group and 1.2 and $1.2 \mathrm{mg} \mathrm{h}^{-1}$ person $^{-1}$ for the adult group. Unfortunately, the agreement between replicates is not as good as it might initially appear. The chamber was at different temperatures for each of the replicate experiments (26.6 and $28.0{ }^{\circ} \mathrm{C}$ for the teenage group; 28.2 and $29.7^{\circ} \mathrm{C}$ for the adult group). This complicates comparison of "replicates" because we expect a higher emission rate at a higher temperature (see next section). The replicate measurement for the adult group gives us a sense of the disagreement between replicates. The $1.2 \mathrm{mg} \mathrm{h}^{-1}$ emission rate at $28.2{ }^{\circ} \mathrm{C}$ is $9 \%$ larger than that calculated for this temperature using eq 2 (next section); the $1.2 \mathrm{mg} \mathrm{h}^{-1}$ emission rate at $29.7{ }^{\circ} \mathrm{C}$ is $30 \%$ smaller than that calculated for this temperature using eq 2 . Based on the replicates for the teenagers and the replicates for the adults, we crudely estimate that the relative standard deviation (RSD) for repeated experiments is approximately $30 \%$. This is larger than the relative error between the two different methods (steady-state and integral mass balance) for calculating the emission rate. The important point is that the difference between emission rates measured in experiments investigating the impact of a parameter must be significantly larger than this RSD (30\%) to be considered indicative of a true effect.

Influence of Various Parameters. Multivariate step-wise linear regression analysis identified temperature (continuous) and clothing level (short vs long) as significant predictors of the estimated $\mathrm{NH}_{3}$ emission rates at inclusion criteria of $p<$ 0.2 . These two significant variables explained $85 \%$ of the variability in the emission rates, with temperature being the more significant $(p<0.0005)$.

Temperature. Figure S3 shows the effect of temperature on $\mathrm{NH}_{3}$ concentrations under both high and low relative humidity conditions (volunteers wearing long clothing). Regardless of humidity, the $\mathrm{NH}_{3}$ concentrations at higher temperatures $\left(32.4\right.$ and $32.6{ }^{\circ} \mathrm{C}$ ) are approximately three to four times higher than at a lower temperature $\left(28.2^{\circ} \mathrm{C}\right)$. Throughout these experiments, higher temperatures were associated with higher $\mathrm{NH}_{3}$ concentrations and higher emission rates under otherwise similar conditions (Table 1). Indeed, there was a strong correlation between the $\mathrm{NH}_{3}$ emission rate and temperature (Figure 1). The correlation derived from the experiments with adults and seniors wearing long clothing $\left(R^{2}\right.$ $=0.92)$ can be expressed as follows

$$
\ln (E)=-27.5 \times\left(\frac{1000}{T}\right)+91.4
$$

where $E$ is the $\mathrm{NH}_{3}$ emission rate from an adult $\left(\mathrm{mg} \mathrm{h}^{-1}\right.$ person $^{-1}$ ), and $T$ is the temperature $(\mathrm{K})$. Based on eq 2 , the emission rate of $\mathrm{NH}_{3}$ for adults and seniors (long clothing) is estimated to be $0.41 \mathrm{mg} \mathrm{h}^{-1}$ person $^{-1}$ at $25^{\circ} \mathrm{C}, 0.77 \mathrm{mg} \mathrm{h}^{-1}$ person $^{-1}$ at $27{ }^{\circ} \mathrm{C}$, and $1.4 \mathrm{mg} \mathrm{h}^{-1}$ person $^{-1}$ at $29{ }^{\circ} \mathrm{C}$.

Ampollini et al. ${ }^{29}$ found a significant correlation between the natural logarithm of background $\mathrm{NH}_{3}$ concentrations measured in a test house and the inverse of temperature during the HOMEChem experiments. However, eq 2 addresses a 


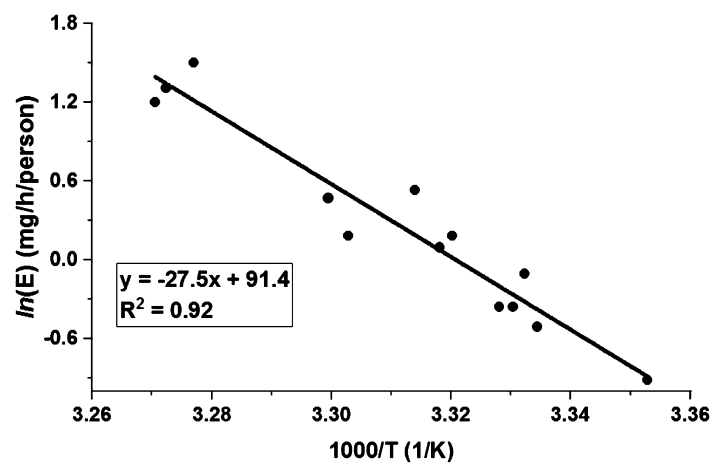

Figure 1. Correlation of the natural log of the $\mathrm{NH}_{3}$ emission rate $(\ln (E))$ vs $(1000 / T)$ using data from the "long-sleeved shirts/pants" experiments with adults and seniors as listed in Table 1.

correlation that is fundamentally different from that reported by Ampollini et al. ${ }^{29}$ In the latter, surfaces were a large reservoir for $\mathrm{NH}_{3}$, and the temperature dependence was presumably because of changes in surface/air partitioning with changing temperature. In the present study, the observed relationship between the $\mathrm{NH}_{3}$ emission rate and temperature likely reflects changes in physiological and microbial factors, as well as skin/air partitioning. Future studies on the temperature dependence of $\mathrm{NH}_{3}$ emission rates should be conducted at lower temperatures, closer to those typically recommended for indoor environments.

Clothing. The fraction of skin covered by clothing had a substantial effect on $\mathrm{NH}_{3}$ concentrations and emission rates. As shown in Figure 2, under identical high $\mathrm{T}$, high $\mathrm{RH}$

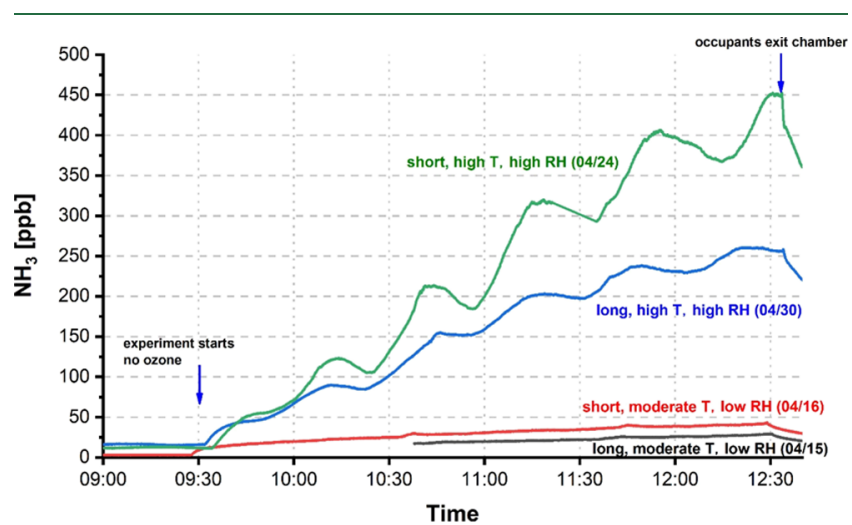

Figure 2. Effect of clothing on $\mathrm{NH}_{3}$ concentrations during the experiments on April 24 (short clothing, high temperature, high $\mathrm{RH}$, and adult group A1), April 30 (long clothing, high temperature, high $\mathrm{RH}$, and adult group A1), April 16 (short clothing, moderate temperature, low $\mathrm{RH}$, and adult group A2), and April 15 (long clothing, moderate temperature, low $\mathrm{RH}$, and adult group $\mathrm{A} 2$ ).

conditions, and with "short" clothing, the $\mathrm{NH}_{3}$ concentrations reached $450 \mathrm{ppb}$ over $3 \mathrm{~h}$ with a calculated emission rate of 5.2 $\mathrm{mg} \mathrm{h}^{-1}$ person $^{-1}$ while with "long" clothing, it only reached $250 \mathrm{ppb}$ with a calculated emission rate of $3.3 \mathrm{mg} \mathrm{h}^{-1}$ person $^{-1}$. Under identical moderate temperature, low humidity conditions, and with "short" clothing, the calculated emission rate was $0.57 \mathrm{mg} \mathrm{h}^{-1}$ person $^{-1}$, whereas with "long" clothing, it was $0.35 \mathrm{mg} \mathrm{h}^{-1}$ person $^{-1}$.

A fresh set of clean clothing was worn each day. Clean clothes may retain $\mathrm{NH}_{3}$ emitted by the skin, reducing its emission to room air. Over time, as the capacity of clothing for
$\mathrm{NH}_{3}$ is approached, clothes may be less effective at reducing $\mathrm{NH}_{3}$ emission rates. The capacity of clothing for sorption of $\mathrm{NH}_{3}$ increases as the $\mathrm{pH}$ of water associated with clothing decreases. ${ }^{8}$ It is also possible that air between skin and the clothing reaches a high $\mathrm{NH}_{3}$ concentration, retarding further $\mathrm{NH}_{3}$ emission.

Dermal Versus Breath Emissions. Several observations indicate that $\mathrm{NH}_{3}$ dermal emission rates are substantially larger than $\mathrm{NH}_{3}$ breath emission rates. The most direct evidence comes from the dermal-only measurements (May 2 and May 7) compared to the breath-only measurements (May 3 and May 6) conducted using the same four volunteers (Table 1). To isolate dermally emitted $\mathrm{NH}_{3}$ from exhaled $\mathrm{NH}_{3}$, the volunteers sat in one chamber with breathing masks covering their mouth and nose and exhaled into an adjacent twin chamber. One-way valves in the masks ensured that the volunteers inhaled air from the chamber where they were seated and exhaled into the adjacent twin chamber. Details are provided in Bekö et al. ${ }^{42}$ The dermal-only emission rate on May $2\left(31.0{ }^{\circ} \mathrm{C}\right.$, high $\mathrm{RH}$, short clothing) was $4.4 \mathrm{mg} \mathrm{h}^{-1}$ person $^{-1}$ while the breath-only emission rate on May 3 (32.5 ${ }^{\circ} \mathrm{C}$, high $\mathrm{RH}$ ) was $>0.027 \mathrm{mg} \mathrm{h}^{-1}$ person $^{-1}$. The dermal-only emission rate on May $7\left(27.9^{\circ} \mathrm{C}\right.$, low $\mathrm{RH}$, short clothing) was $0.92 \mathrm{mg} \mathrm{h}^{-1}$ person $^{-1}$ while the breath-only emission rate on May $6\left(26.1{ }^{\circ} \mathrm{C}\right.$, low $\left.\mathrm{RH}\right)$ was $>0.017 \mathrm{mg} \mathrm{h}^{-1}$ person $^{-1}$. The breath emission rates are reported as lower limits because $\mathrm{NH}_{3}$ concentrations did not reach the steady state in the "breath chamber". Nonetheless, these lower bounds are substantially smaller than the dermal-only emission rates measured under comparable conditions. Even if the breath emission rates are three times these lower limits, they would still be 15 to 50 times smaller than the dermal emission rates measured for similar temperatures, $\mathrm{RH}$, and clothing coverage. It is noteworthy that the lower limits measured for the breath emission rates are close to $\mathrm{NH}_{3}$ emission rates reported for nose breathing in previous studies ${ }^{31,36,37}$ (Table 2).

Another piece of evidence for the dominance of dermal over breath emissions in the present study comes from the observation that dermal-only emission rates are relatively close in value to whole body emission rates for similar conditions. The dermal-only $\mathrm{NH}_{3}$ emission rate was $4.4 \mathrm{mg}$ $\mathrm{h}^{-1}$ person $^{-1}$ on May 2 (Group A3, 31.0 ${ }^{\circ} \mathrm{C}$, high $\mathrm{RH}$, and short clothing) while the whole body emission rate was $5.2 \mathrm{mg}$ $\mathrm{h}^{-1}$ person $^{-1}$ on April 24 (Group A1, $32.6{ }^{\circ} \mathrm{C}$, high $\mathrm{RH}$, and short clothing). The dermal-only emission rate on May 7 (Group A3, $27.9^{\circ} \mathrm{C}$, low $\mathrm{RH}$, and short clothing) was $0.92 \mathrm{mg}$ $\mathrm{h}^{-1}$ person $^{-1}$ while the whole body emission rate on April 16 (Group A2, $25.6{ }^{\circ} \mathrm{C}$, low $\mathrm{RH}$, and short clothing) was $0.57 \mathrm{mg}$ $\mathrm{h}^{-1}$ person $^{-1}$. The somewhat larger dermal-only emission rate in the latter comparison likely reflects the higher chamber temperature during the dermal-only experiment $\left(27.9^{\circ} \mathrm{C}\right)$ compared to the whole body experiment $\left(25.6^{\circ} \mathrm{C}\right)$. The key point is that the difference between dermal-only and whole body emission rates is relatively small and precludes large values for the breath-only emission rates.

The strong influence of clean clothing on $\mathrm{NH}_{3}$ emission rates (see previous subsection Clothing) provides additional evidence that dermal emissions tend to be larger than breath emissions in these chamber experiments. Taken together, these observations indicate only a small contribution from breath to whole body emission rates. This is supported by previous studies, which indicate that for typical breathing patterns, dermal $\mathrm{NH}_{3}$ emission rates are larger than breath $\mathrm{NH}_{3}$ 
Table 2. Summary of Studies Reporting Ammonia Emissions from Nose Breath, Mouth Breath, Lower Forearm, Multiple Skin Locations, or the Whole Body

\begin{tabular}{|c|c|c|c|c|c|}
\hline study & analytical method & sampling & subjects & age & avg emission rate $\mathrm{mg} / \mathrm{h} /$ person \\
\hline $\begin{array}{l}\text { Larson et al. } \\
1977 \text { (31) }\end{array}$ & $\begin{array}{l}\mathrm{NH}_{3} \text { to } \mathrm{NO} \\
\text { converter/NO analyzer }\end{array}$ & nose breath, mouth breath & 9 males, 7 females & $23-63$ & nose: 0.017 , mouth: 0.11 \\
\hline $\begin{array}{l}\text { Nose et al. } 2005 \\
\quad(32)\end{array}$ & $\begin{array}{l}\mathrm{GC} / \text { flame thermionic } \\
\text { detector }\end{array}$ & lower forearm & $28(\text { sex not reported })^{a}$ & $56-86$ & dermal: 0.41 \\
\hline $\begin{array}{l}\text { Turner et al. } \\
2006(33)\end{array}$ & $\begin{array}{l}\text { selected ion flow tube- } \\
\text { mass spectrometry }\end{array}$ & mouth breath & 19 males, 11 females & $24-59$ & mouth: 0.39 \\
\hline $\begin{array}{l}\breve{S} \text { Spanel et al. } \\
2007 \mathrm{a}(35)\end{array}$ & $\begin{array}{l}\text { selected ion flow tube- } \\
\text { mass spectrometry }\end{array}$ & mouth breath & 10 males, 16 females & $17-19$ & mouth: 0.15 \\
\hline $\begin{array}{l}\text { Španel et al. } \\
2007 \mathrm{~b}(34)\end{array}$ & $\begin{array}{l}\text { selected ion flow tube- } \\
\text { mass spectrometry }\end{array}$ & mouth breath & $\begin{array}{l}\text { children: } 2 \text { males, } 2 \text { females, seniors: } \\
10 \text { males, } 3 \text { females }\end{array}$ & $\begin{array}{r}4-6 \text { and } \\
60-83\end{array}$ & $\begin{array}{l}\text { mouth: children: } 0.19 \text {, seniors: } \\
0.50\end{array}$ \\
\hline $\begin{array}{l}\text { Smith et al., } 2008 \\
(36)\end{array}$ & $\begin{array}{l}\text { selected ion flow tube- } \\
\text { mass spectrometry }\end{array}$ & nose breath, mouth breath & 3 males & $>30$ & nose: 0.046 , mouth: 0.44 \\
\hline $\begin{array}{l}\text { Schmidt et al. } \\
2013(37)\end{array}$ & $\begin{array}{l}\text { cavity ring-down } \\
\text { spectroscopy }\end{array}$ & $\begin{array}{l}\text { nose breath, mouth breath, } \\
\text { lower forearm }\end{array}$ & 13 males, 7 females & $22-61$ & $\begin{array}{l}\text { nose: } 0.016 \text {, mouth: } 0.32 \text {, } \\
\text { dermal: } 0.36\end{array}$ \\
\hline $\begin{array}{l}\text { Chen et al., } 2014 \\
\text { (38) }\end{array}$ & $\begin{array}{l}\text { cavity ring-down } \\
\text { spectroscopy }\end{array}$ & mouth breath & 22 males, 8 females & $19-60$ & mouth: 0.38 \\
\hline $\begin{array}{l}\text { Furukawa et al. } \\
2017(40)\end{array}$ & ion chromatography & thirteen skin locations & 5 males, 5 females & $21-23$ & dermal: $5.9^{b}$ \\
\hline This work & $\begin{array}{l}\text { cavity ring-down } \\
\text { spectroscopy }\end{array}$ & $\begin{array}{l}\text { whole body, breath, } \\
\text { dermal }\end{array}$ & 11 males, 9 females & $13-72$ & $\begin{array}{l}\text { whole body: } 0.4-5.2^{c} \text {; see text } \\
\text { for breath \& dermal }\end{array}$ \\
\hline
\end{tabular}

${ }^{a}$ Healthy subjects. They also measured subjects with hepatic disease, not reported in this table. ${ }^{b}$ This value is likely high due to sweating under the sealed passive sampler affixed to the skin. ${ }^{c}$ Emission rate varied with temperature; see text.

emission rates (see subsection Prior Emission Rate Measurements and Table 2). We anticipate that $\mathrm{NH}_{3}$ breath emissions vary less with temperature than dermal emissions, meaning that at lower temperatures, the dominance of dermal compared to breath emissions will be diminished.

Age. To discern the impact of age on $\mathrm{NH}_{3}$ emission rates, we evaluated, in addition to the adult groups (19-30 years old), two other sets of four volunteers: a teen group 13-15 years old, and a senior group 68-72 years old. Figure S4 displays measured $\mathrm{NH}_{3}$ concentrations versus time for chamber experiments with each of these groups under similar conditions $\left(25-28{ }^{\circ} \mathrm{C}, 25-35 \% \mathrm{RH}\right.$, long clothing). The emission rates of teenagers $\left(1.2\right.$ at $26.6{ }^{\circ} \mathrm{C}$ and $1.5 \mathrm{mg} \mathrm{h}^{-1}$ person $^{-1}$ at $28.0{ }^{\circ} \mathrm{C}$ ) were higher than those of adults at comparable temperatures $\left(0.60\right.$ at $27.1{ }^{\circ} \mathrm{C}$ and $1.1 \mathrm{mg} \mathrm{h}^{-1}$ person ${ }^{-1}$ at $\left.28.2^{\circ} \mathrm{C}\right)$ and seniors $\left(0.74 \mathrm{mg} \mathrm{h}^{-1}\right.$ person $^{-1}$ at 27.1 ${ }^{\circ} \mathrm{C}$ ) (Table 1). Given that breath emission rates in the present study are substantially smaller than dermal emission rates (see subsection Dermal Versus Breath Emissions), the higher measured $\mathrm{NH}_{3}$ emission rate from the teenage group presumably is primarily because of differences in dermal emission rates among the three groups. This may reflect differences in sweating, diet, or metabolic rates among the groups. However, the relative differences reported above and displayed in Figure S4 are not substantially different from the RSD of $\sim 30 \%$ observed in the reproducibility experiments. Further experiments, with a larger number of subjects, are warranted to confirm this preliminary observation of higher emission rates for the teenage volunteers.

Humidity. Humidity was found to have a small influence on the measured $\mathrm{NH}_{3}$ concentrations and a negligible influence on $\mathrm{NH}_{3}$ emission rates. Figure $\mathrm{S} 5$ shows the $\mathrm{NH}_{3}$ concentrations on two experimental days with different humidities under otherwise identical conditions $(\Delta T=0.2$ $\left.{ }^{\circ} \mathrm{C}\right)$. The calculated $\mathrm{NH}_{3}$ emission rates at low $\mathrm{RH}\left(3.7 \mathrm{mg} \mathrm{h}^{-1}\right.$ person $^{-1}$ at high temperature and $1.1 \mathrm{mg} \mathrm{h}^{-1}$ person $^{-1}$ at moderate temperature) were not substantially different from those at high $\mathrm{RH}\left(3.4 \mathrm{mg} \mathrm{h}^{-1}\right.$ person $^{-1}$ at high temperature and $1.2 \mathrm{mg} \mathrm{h}^{-1}$ person $^{-1}$ at moderate temperature) (Table 1).
Indeed, the relative difference between the low and high $\mathrm{RH}$ conditions was smaller than the RSD estimated from the replicate experiments.

Skin moisture measurements made during these experiments support the fact that more sweating occurred at high $\mathrm{T} /$ high $\mathrm{RH}$ than at moderate $\mathrm{T} /$ low $\mathrm{RH}^{42}$ To the extent that the room humidity influences sweating and stress, ${ }^{47}$ we would anticipate higher $\mathrm{NH}_{3}$ emission rates at higher relative humidity. On the other hand, additional sweat on the surface of skin increases its capacity to retain gas-phase $\mathrm{NH}_{3}$.

Given that the sorptive capacity of indoor surfaces for $\mathrm{NH}_{3}$ is larger at higher relative humidities, we expect that it takes longer to reach steady-state $\mathrm{NH}_{3}$ concentrations at higher relative humidities. The $\mathrm{NH}_{3}$ concentrations under high humidity followed an oscillating pattern anticorrelating with that of relative humidity (Figures 2 and S3) as the humidifier in the HVAC system cycled on and off. When the humidifier was on, the $\mathrm{NH}_{3}$ level was lower than when the humidifier was off, presumably because of more sorbed water on chamber surfaces coupled with ammonia's large Henry's constant (59 $\mathrm{M} / \mathrm{atm}$ ). Such behavior has been seen for water-soluble gases in other studies (e.g., Duncan et al. $^{48}$ ).

Ozone. The rate at which ozone reacts with $\mathrm{NH}_{3}$ in the gas phase is relatively slow ${ }^{49}$ - too slow for this reaction to compete with the air change rate $\left(3.2 \mathrm{~h}^{-1}\right)$ in these chamber studies. In experiments with teenagers and seniors, we explored the possibility that ozone indirectly affected $\mathrm{NH}_{3}$ emission rates. In these investigations, ozone was either present or absent from the beginning of exposure (9:30) until the volunteers left the chamber (12:30). Figure S6 displays plots of $\mathrm{NH}_{3}$ concentration versus time from these experiments. For teenagers on May $18\left(27.3^{\circ} \mathrm{C}\right)$, with the presence of ozone, the estimated emission rate was $1.0 \mathrm{mg} \mathrm{h}^{-1}$ person $^{-1}$. On May $17\left(26.6{ }^{\circ} \mathrm{C}\right)$ and May $19\left(28.0{ }^{\circ} \mathrm{C}\right)$, with the absence of ozone, the estimated emission rates were 1.2 and $1.5 \mathrm{mg} \mathrm{h}^{-1}$ person $^{-1}$. The difference among emission rates measured on these three dates may reflect the higher chamber temperature on May 19 compared to May 17 and May 18, as well as limits on the reproducibility of such experiments. For seniors, on 
May $14\left(27.3^{\circ} \mathrm{C}\right)$, with the presence of ozone, the emission rate was $0.66 \mathrm{mg} \mathrm{h}^{-1}$ person $^{-1}$. On May $15\left(27.1^{\circ} \mathrm{C}\right)$, with the absence of ozone, the emission rate was $0.74 \mathrm{mg} \mathrm{h}^{-1}$ person $^{-1}$. The variation is smaller than that among the replicate experiments. Hence, these results suggest that the $\mathrm{NH}_{3}$ emission rate is negligibly affected by the presence of ozone.

In a number of experiments, after a morning period with no ozone in the chamber, the subjects exited, had a light lunch (bread, butter, and sliced cheese), and re-entered the chamber where the ozone generators were turned on $10 \mathrm{~min}$ later (e.g., see May 15, 17, and 19 in Figure S6). On first inspection, it appears that the introduction of ozone caused an increase in $\mathrm{NH}_{3}$ concentrations. However, closer inspection indicates that this is not the case. Returning to Figure S6, for both teenagers and seniors, there is (i) a day with ozone already present at $9: 30$ that ends at 12:30; (ii) days without ozone in the morning, with ozone added in the afternoon. On all 5 days, $\mathrm{NH}_{3}$ concentrations had come close to steady-state values by 12:30 when the volunteers left the chamber. This indicates that, for either the pair of experiments with teenagers or the pair with seniors, on the day when ozone was added in the afternoon, it should not have resulted in substantially higher $\mathrm{NH}_{3}$ levels than measured on the day when ozone was already in the chamber in the morning. The afternoon increases in $\mathrm{NH}_{3}$ concentrations are caused by something other than ozone, most likely the light lunch. It is known that eating, especially high protein foods such as cheese, can increase $\mathrm{NH}_{3}$ emission rates. ${ }^{37,50}$ The difference between morning and afternoon $\mathrm{NH}_{3}$ emission rates in Table $1\left(\sim 0.5\right.$ to $1 \mathrm{mg} \mathrm{h}^{-1}$ person $^{-1}$ ) may be indicative of the impact of eating on these rates.

Prior Emission Rate Measurements. Prior to this investigation, there have only been a limited number of studies that have measured $\mathrm{NH}_{3}$ emission rates from humans. ${ }^{31-38,40}$ Table 2 summarizes these.

Larson et al. ${ }^{31}$ measured $\mathrm{NH}_{3}$ concentrations in exhaled mouth and nose breath. For nine males and seven females (age 23-63), the median concentration in mouth breath was 244 ppb, ranging from 42 to $748 \mathrm{ppb}$. For five male subjects, the median concentration in nose breath was $36 \mathrm{ppb}$ (range 19$66 \mathrm{ppb})$.

Nose et $\mathrm{al}^{32}$ measured dermal emissions from the lower forearm or finger of 28 healthy volunteers (age $71 \pm 15$ ) and 24 volunteers with hepatic disease (age $64 \pm 16$ ). For forearm sampling, helium passed through a small polytetrafluoroethylene enclosure affixed to the skin. Prior to measurements, skin surfaces were washed with tap water and patted dry. The mean $\mathrm{NH}_{3}$ emissions from the lower forearm were significantly lower for healthy volunteers $\left(20 \pm 4.8 \mathrm{ng} / \mathrm{cm}^{2} / \mathrm{h}\right)$ than hepatic ones $\left(32 \pm 9.6 \mathrm{ng} / \mathrm{cm}^{2} / \mathrm{h}\right)$. The $\mathrm{NH}_{3}$ emission rate correlated with $\mathrm{NH}_{3}$ concentration in blood $(r=0.64)$.

Turner et al. ${ }^{33}$ measured $\mathrm{NH}_{3}$ concentration in the exhaled breath of 19 males and 11 females (age 24-59). The breath samples were collected prior to lunch. The measured concentration distribution was close to log-normal, with a median concentration of $833 \mathrm{ppb}$ (range 248-2935 ppb). Males and females had similar $\mathrm{NH}_{3}$ breath concentrations. Older subjects had higher breath concentrations than younger ones. The variation in $\mathrm{NH}_{3}$ levels among volunteers (32\%) was similar to that for repeated measurements with the same subject $(37 \%)$.

Spanel et al. $^{35}$ analyzed the mouth breath emissions of several chemicals from 26 school pupils aged 17-19. The concentrations were log normally distributed, with a median value for $\mathrm{NH}_{3}$ of $317 \mathrm{ppb}$. In a co-occurring study, ${ }^{34}$ they measured mouthbreath $\mathrm{NH}_{3}$ levels of $\sim 200 \mathrm{ppb}$ for four children (age 4-6) and a median concentration of $1080 \mathrm{ppb}$ for 13 seniors (age 60-83). They concluded that there was an increase in mouth breath $\mathrm{NH}_{3}$ concentrations with age, acknowledging the relatively small number of samples.

Smith et al. ${ }^{36}$ measured $\mathrm{NH}_{3}$ concentrations in nose and mouth breath, as well as in the oral cavity, of three healthy males (age >30). Ammonia in nose breath ranged from 83$103 \mathrm{ppb}$; in mouth breath ranged from $855-1090 \mathrm{ppb}$; and in the oral cavity ranged from $1470-2150$. They concluded that $\mathrm{NH}_{3}$ in mouth breath is largely generated in the oral cavity, “... presumably being produced by the action of bacteria and/or salivary enzymes on nitrogenous compounds such as systemic urea".

Schmidt et al. ${ }^{37}$ measured $\mathrm{NH}_{3}$ concentrations in exhaled breath and emission rates from the forearm of 13 males and 7 females (age 22-61). The volunteers fasted at least $10 \mathrm{~h}$, and forearm skin was washed and dried $30 \mathrm{~min}$ before measurements. The median $\mathrm{NH}_{3}$ concentration in mouth breath was $688 \pm 396 \mathrm{ppb}$, similar to Turner et al. ${ }^{33}$ (830 ppb) and somewhat higher than Larson et al. ${ }^{31}(240 \mathrm{ppb})$. The median $\mathrm{NH}_{3}$ concentration in nose breath was $34 \pm 32 \mathrm{ppb}$, in good agreement with Larson et al. ${ }^{31}$ (36 ppb). The median $\mathrm{NH}_{3}$ emission rate from the lower forearm was $18 \pm 36 \mathrm{ng} / \mathrm{cm}^{2} / \mathrm{h}$, in agreement with Nose et al. $\left(20 \pm 4.8 \mathrm{ng} / \mathrm{cm}^{2} / \mathrm{h}\right) .^{32}$ Rinsing with an acidic mouthwash reduced the median $\mathrm{NH}_{3}$ concentration in mouth breath and nose breath to $21 \mathrm{ppb}$. Increasing the acidity of saliva decreases the ratio of gas-phase $\mathrm{NH}_{3}(\mathrm{~g})$ to the sum of $\mathrm{NH}_{3}(\mathrm{aq})+\mathrm{NH}_{4}{ }^{+}$in saliva. Norwood et al. ${ }^{50}$ previously reported that $\mathrm{NH}_{3}$ concentrations in mouth breath decreased by approximately $90 \%$, following rinsing with lemon juice ( $\mathrm{pH} 2.5$ ).

Chen et al. ${ }^{38}$ measured a mean $\mathrm{NH}_{3}$ concentration of 630 $\mathrm{ppb}$ in the mouth breath of 30 volunteers. They also measured oral fluid $\mathrm{NH}_{3}$ and urea for these same volunteers. They found a significant correlation between oral fluid $\left(\mathrm{NH}_{4}^{+}+\mathrm{NH}_{3}\right)$ and oral fluid urea, as well as a correlation between $\mathrm{NH}_{3}$ in mouth breath and oral fluid $\mathrm{NH}_{3}$. They concluded that oral fluid urea is a dominant contributor to oral fluid $\left(\mathrm{NH}_{4}^{+}+\mathrm{NH}_{3}\right)$ and thus a significant source of $\mathrm{NH}_{3}$ in mouth breath.

Furukawa et al. ${ }^{40}$ measured dermal emissions from 13 locations on 5 males and 5 females (age 21-23). $\mathrm{NH}_{3}$ emissions were collected using passive flux samplers affixed/ sealed to the skin for $1 \mathrm{~h}$. Higher $\mathrm{NH}_{3}$ emissions were measured on the feet, back, and lumbar region, and lower emissions were measured on upper arms, buttocks, thighs, and lower legs. This ranking roughly corresponds to the density of sweat glands at the different body locations. The median $\mathrm{NH}_{3}$ flux from the lower forearm was $270 \mathrm{ng} / \mathrm{cm}^{2} / \mathrm{h}$, much higher than Nose et al. ${ }^{32}\left(20 \mathrm{ng} / \mathrm{cm}^{2} / \mathrm{h}\right)$ and Schmidt et al. ${ }^{37}$ (18 ng/ $\mathrm{cm}^{2} / \mathrm{h}$ ). Passive flux sampling over a $1 \mathrm{~h}$ interval from covered/ sealed skin may have resulted in artificially high values because elevated temperatures and sweating are anticipated under such conditions (total ammonia, $\mathrm{NH}_{3}+\mathrm{NH}_{4}^{+}$, is typically 500$8000 \mu \mathrm{mol} \mathrm{L}^{-1}$ in sweat $\left.{ }^{51}\right)$. Calculated whole body emission rates, based on the fractional body surface area of each sampled anatomical region, averaged $5.9 \pm 3.2 \mathrm{mg} \mathrm{h}^{-1}$ person $^{-1}$ (range 2.9-12 $\mathrm{mg} \mathrm{h}^{-1}$ person $^{-1}$ ).

The last column of Table 2 lists $\mathrm{NH}_{3}$ emission $\left(\mathrm{mg} \mathrm{h}^{-1}\right.$ person $^{-1}$ ) estimated from breath and forearm measurements in this work. To convert breath concentrations to emission rates, 
we assumed a breathing rate of $16 \mathrm{~m}^{3} /$ day; to convert emissions from the lower forearm to whole body emission rates, we assumed a total body surface area of $2 \mathrm{~m}^{2}$. These assumptions are supported by data in the U.S. EPA Exposure Factors Handbook. ${ }^{52}$ Taken together, the results of Larson et al., ${ }^{31}$ Nose et al., ${ }^{32}$ Turner et al., ${ }^{33}$ and Schmidt et al. ${ }^{37}$ indicate that total emission rates (i.e., sum of breath and dermal) are anticipated to be in the range of $0.5-0.7 \mathrm{mg} \mathrm{h}^{-1}$ person $^{-1}$. Such emission rates are consistent with values measured in the present study for fully clothed subjects at moderate $\mathrm{T}$ and smaller than values for fully clothed subjects at high $\mathrm{T}$ (see Table 1). At high $\mathrm{T}$, sweat likely contributed to the measured $\mathrm{NH}_{3}$ emissions rates. The latter are close to the mean value reported by Furukawa et al. ${ }^{40}$ for what were likely high $\mathrm{T}$ and high $\mathrm{RH}$ conditions (sealed passive sampler affixed to skin for an hour).

Ampollini et al. ${ }^{29}$ measured $\mathrm{NH}_{3}$ in a test house at the University of Texas, Austin, using the same type of CRDS used in the present study. Real-time simultaneous measurements of $\mathrm{CO}_{2}$ and $\mathrm{NH}_{3}$ concentrations from this study can be used to estimate $\mathrm{NH}_{3}$ emission rates. Figure $6 \mathrm{~b}$ of the cited paper ${ }^{29}$ shows plots of the change in $\mathrm{NH}_{3}$ concentrations versus the change in $\mathrm{CO}_{2}$ concentrations during sequential time periods on a day that three groups toured the house. Assuming an average $\mathrm{CO}_{2}$ emission rate for an adult ${ }^{53}$ of $4.33 \times 10^{4} \mathrm{mg} \mathrm{h}^{-1}$, and using the slopes reported for the $\Delta \mathrm{NH}_{3}$ versus $\Delta \mathrm{CO}_{2}$ plots in Figure $6 \mathrm{~b}$, we estimate $\mathrm{NH}_{3}$ emission rates of 0.25 , 0.50 , and $0.80 \mathrm{mg} \mathrm{h}^{-1}$ person $^{-1}$ for Tour 1 , Tour 2 , and Tour 3 , respectively. The surfaces in the test house were likely sinks for $\mathrm{NH}_{3}$ during the tours because there was insufficient time to reach steady-state condition. The $\mathrm{NH}_{3}$ emission rate estimated for Tour 3 is anticipated to be closest to an accurate value. The estimate based on Tour 3 is roughly consistent with the emission rates measured in the present study at moderate $\mathrm{T}$.

Broader Implications. In indoor environments, $\mathrm{NH}_{3}$ is the dominant neutralizer of acidity in indoor airborne particles, aqueous surface films, and bulk water. Its indoor concentration is typically three orders of magnitude higher than those of organic amines, excepting nicotine, the next most abundant basic species indoors. ${ }^{8}$ Ammonia has substantially larger Henry's constant than carbon dioxide ( $59 \mathrm{M} /$ atm vs 0.033 $\mathrm{M} / \mathrm{atm}) .{ }^{54}$ It is also more basic than carbon dioxide is acidic $\left(\mathrm{pK} \mathrm{a}_{\mathrm{a}}: \mathrm{NH}_{4}^{+}\right.$9.25; $\mathrm{H}_{2} \mathrm{CO}_{3}$ 6.35). ${ }^{8}$ Consequently, when considering water equilibrated with $\mathrm{NH}_{3}$ and carbon dioxide in indoor air, one $\mathrm{ppb}$ of $\mathrm{NH}_{3}$ neutralizes the impact of 71,000 $\mathrm{ppb}$ of $\mathrm{CO}_{2} .{ }^{8}$ Given that the average $\mathrm{CO}_{2}$ emission rate for an adult is $4.33 \times 10^{4} \mathrm{mg} \mathrm{h}^{-1}$, and that the molecular weights of $\mathrm{CO}_{2}$ and $\mathrm{NH}_{3}$ are 44 and $17 \mathrm{gm} /$ mole, respectively, an $\mathrm{NH}_{3}$ emission rate of $0.24 \mathrm{mg} \mathrm{h}^{-1}$ person ${ }^{-1}$ is sufficient to neutralize the acidifying impact of carbon dioxide from human breath. This $\mathrm{NH}_{3}$ emission rate is smaller than the values we report in Table 1.

The emission rates measured in the present study, under various defined environmental conditions, allow better estimates of $\mathrm{NH}_{3}$ concentrations in indoor settings with different occupant densities, temperatures, and fraction of exposed skin. Figure S7 displays plots of indoor $\mathrm{NH}_{3}$ concentrations, under a range of indoor conditions, estimated with emission rates measured in this study and a simple mass balance model. These estimated indoor concentrations range from about 5 to $100 \mathrm{ppb}$. More accurate $\mathrm{NH}_{3}$ emission rates for humans result in better estimates of the impact of humans on the acid-base chemistry in the buildings they occupy, and such acid-base chemistry strongly influences sorptive capacity of indoor surfaces for volatile acidic and basic species, impacting overall indoor air quality. ${ }^{8}$

As a consequence of indoor-to-outdoor transport, $\mathrm{NH}_{3}$ emitted indoors also contributes to outdoor $\mathrm{NH}_{3}$ concentrations. ${ }^{4}$ Using human $\mathrm{NH}_{3}$ emission rates similar to those measured in the present study, Zheng et al. ${ }^{55}$ estimated that humans contribute $\sim 5 \%$ to the net $\mathrm{NH}_{3}$ emissions in Dongguan, China and $\sim 2 \%$ in Shenzhen. The contribution of human emissions to total $\mathrm{NH}_{3}$ emissions in urban areas is anticipated to be highest in hot, densely populated cities (e.g., Hong Kong, Manila, Mexico City, Delhi, Mumbai) and to increase as temperatures in urban areas increase. The measurements made in the present study allow better estimates of $\mathrm{NH}_{3}$ emissions at different temperatures.

\section{ASSOCIATED CONTENT}

\section{SI Supporting Information}

The Supporting Information is available free of charge at https://pubs.acs.org/doi/10.1021/acs.est.0c00094.

Estimation of steady-state concentrations, sigmoidal Boltzmann curve fitting; plots displaying measured $\mathrm{NH}_{3}$ concentrations versus time for replicate experiments; different temperatures; volunteers of different ages; different relative humidities; and different $\mathrm{O}_{3}$ concentrations; plots displaying estimated indoor $\mathrm{NH}_{3}$ concentrations at different occupant densities; ventilation rates; and emission rates; and text describing these estimates (estimated indoor $\mathrm{NH}_{3}$ concentrations for typical indoor conditions) (PDF)

\section{AUTHOR INFORMATION}

\section{Corresponding Authors}

Charles J. Weschler - International Centre for Indoor Environment and Energy, Department of Civil Engineering, Technical University of Denmark, Lyngby 2800, Denmark; Environmental and Occupational Health Sciences Institute, Rutgers University, Piscataway, New Jersey 08854, United

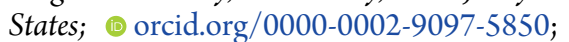
Email: weschlch@rwjms.rutgers.edu

Jonathan Williams - Max Planck Institute for Chemistry, 55128 Mainz, Germany; Email: jonathan.williams@mpic.de

\section{Authors}

Mengze Li - Max Planck Institute for Chemistry, 55128 Mainz, Germany; (ㅇ) orcid.org/0000-0003-0620-6301

Gabriel Bekö - International Centre for Indoor Environment and Energy, Department of Civil Engineering, Technical University of Denmark, Lyngby 2800, Denmark

Pawel Wargocki - International Centre for Indoor Environment and Energy, Department of Civil Engineering, Technical University of Denmark, Lyngby 2800, Denmark

Gregor Lucic - Picarro Inc., Santa Clara, California 95054, United States

Complete contact information is available at: https://pubs.acs.org/10.1021/acs.est.0c00094

\section{Notes}

The authors declare no competing financial interest. 


\section{ACKNOWLEDGMENTS}

We appreciate the loan of G2103 analyzer from Picarro Inc. for measuring ammonia during the ICHEAR experiments. This study was funded by the Alfred P. Sloan Foundation (G-201811233). We thank the volunteers for their participation in the study and Thomas Klüpfel, Rolf Hofmann, and Nico Ziersen for their help with mechanical engineering and transportation.

\section{REFERENCES}

(1) Nagata, Y. Measurement of odor threshold by triangle odor bag method. Odor. Meas. Rev. 2003, 118, 118-127.

(2) Nielsen, G. D.; Wolkoff, P.; Alarie, Y. Sensory irritation: risk assessment approaches. Regul. Toxicol. Pharmacol. 2007, 48, 6-18.

(3) Kruse, M.; Bell, J. Ammonia emissions and their role in acid deposition. Atmos. Environ. 1987, 21, 1939-1946.

(4) Cass, G.; Gharib, S.; Peterson, M.; Tilden, J. The origin of ammonia emissions to the atmosphere in an urban area. Open File Rep. 1982, 82-6, 1-46.

(5) Liu, T.; Wang, X.; Wang, B.; Ding, X.; Deng, W.; Lü, S.; Zhang, $\mathrm{Y}$. Emission factor of ammonia (NH3) from on-road vehicles in China: tunnel tests in urban Guangzhou. Environ. Res. Lett. 2014, 9, 064027.

(6) Schlesinger, W. H.; Hartley, A. E. A global budget for atmospheric $\mathrm{NH}_{3}$. Biogeochemistry 1992, 15, 191-211.

(7) Gerendás, J.; Zhu, Z.; Bendixen, R.; Ratcliffe, R. G.; Sattelmacher, B. Physiological and biochemical processes related to ammonium toxicity in higher plants. J. Plant Nutr. Soil Sci. 1997, 160, 239-251.

(8) Nazaroff, W. W.; Weschler, C. J. Indoor acids and bases. Indoor Air 2020, DOI: 10.1111/ina.12670.

(9) Finlayson-Pitts, B. J.; Pitts, J. N., Jr. Chemistry of the Upper and Lower Atmosphere: Theory, Experiments, and Applications; Elsevier, 1999.

(10) Na, K.; Song, C.; Switzer, C.; Cocker, D. R. Effect of ammonia on secondary organic aerosol formation from $\alpha$-pinene ozonolysis in dry and humid conditions. Environ. Sci. Technol. 2007, 41, 60966102.

(11) Huang, Y.; Lee, S. C.; Ho, K. F.; Ho, S. S. H.; Cao, N.; Cheng, Y.; Gao, Y. Effect of ammonia on ozone-initiated formation of indoor secondary products with emissions from cleaning products. Atmos. Environ. 2012, 59, 224-231.

(12) Niu, X.; Ho, S. S. H.; Ho, K. F.; Huang, Y.; Cao, J.; Shen, Z.; Sun, J.; Wang, X.; Wang, Y.; Lee, S. Indoor secondary organic aerosols formation from ozonolysis of monoterpene: an example of d-limonene with ammonia and potential impacts on pulmonary inflammations. Sci. Total Environ. 2017, 579, 212-220.

(13) DeCarlo, P. F.; Avery, A. M.; Waring, M. S. Thirdhand smoke uptake to aerosol particles in the indoor environment. Sci. Adv. 2018, 4, No. eaap8368.

(14) Collins, D. B.; Hems, R. F.; Zhou, S.; Wang, C.; Grignon, E.; Alavy, M.; Siegel, J. A.; Abbatt, J. P. D. Evidence for Gas-Surface Equilibrium Control of Indoor Nitrous Acid. Environ. Sci. Technol. 2018, 52, 12419-12427.

(15) Pacharra, M.; Kleinbeck, S.; Schäper, M.; Blaszkewicz, M.; van Thriel, C. Multidimensional assessment of self-reported chemical intolerance and its impact on chemosensory effects during ammonia exposure. Int. Arch. Occup. Environ. Health 2016, 89, 947-959.

(16) California Office of Environmental Health Hazard Assessment (OEHHA). Ammonia, Appendix D.2 Acute RELs and Toxicity Summaries. https://oehha.ca.gov/media/downloads/crnr/ appendixd2final.pdf (accessed March 19, 2020).

(17) California Office of Environmental Health Hazard Assessment (OEHHA). Ammonia, Appendix D.2 Chronic RELs and Toxicity Summaries. https://oehha.ca.gov/media/downloads/crnr/ appendixd3final.pdf (accessed March 19, 2020).

(18) Thrane, V. R.; Thrane, A. S.; Wang, F.; Cotrina, M. L.; Smith, N. A.; Chen, M.; Xu, Q.; Kang, N.; Fujita, T.; Nagelhus, E. A.
Ammonia triggers neuronal disinhibition and seizures by impairing astrocyte potassium buffering. Nat. Med. 2013, 19, 1643.

(19) US Department of Health Human Services Public Health Service. Agency for Toxic Substances and Disease Registry; ATSDR, 2004.

(20) Health Safety Executive EH40/2005. Workplace Exposure Limits, 3rd ed.; HSE: Bootle, 2018.

(21) Li, Y.; Harrison, R. M. Comparison of indoor and outdoor concentrations of acid gases, ammonia and their associated salts. Environ. Technol. 1990, 11, 315-326.

(22) Brauer, M.; Koutrakis, P.; Keeler, G. J.; Spengler, J. D. Indoor and outdoor concentrations of inorganic acidic aerosols and gases. J. Air Waste Manag. Assoc. 1991, 41, 171-181.

(23) Liang, C. S. K.; Waldman, J. M. Indoor exposures to acidic aerosols at child and elderly care facilities. Indoor Air 1992, 2, 196207.

(24) Suh, H. H.; Spengler, J. D.; Koutrakis, P. Personal exposures to acid aerosols and ammonia. Environ. Sci. Technol. 1992, 26, 25072517.

(25) Atkins, D. H. F.; Lee, D. S. Indoor concentrations of ammonia and the potential contribution of humans to atmospheric budgets. Atmos. Environ. 1993, 27, 1-7.

(26) Spengler, J. D.; Brauer, M.; Samet, J. M.; Lambert, W. E. Nitrous acid in Albuquerque, New Mexico, homes. Environ. Sci. Technol. 1993, 27, 841-845.

(27) Suh, H.; Koutrakis, P.; Spengler, J. The relationship between airborne acidity and ammonia in indoor environments. J. Expo. Anal. Environ. Epidemiol. 1994, 4, 1-22.

(28) Leaderer, B. P.; Naeher, L.; Jankun, T.; Balenger, K.; Holford, T. R.; Toth, C.; Sullivan, J.; Wolfson, J. M.; Koutrakis, P. Indoor, outdoor, and regional summer and winter concentrations of $\mathrm{PM}_{10}$ $\mathrm{PM}_{2.5}, \mathrm{SO}_{4}{ }^{2-}, \mathrm{H}^{+}, \mathrm{NH}_{4}^{+}, \mathrm{NO}_{3}{ }^{-}, \mathrm{NH}_{3}$, and nitrous acid in homes with and without kerosene space heaters. Environ. Health Perspect. 1999, $107,223-231$.

(29) Ampollini, L.; Katz, E. F.; Bourne, S.; Tian, Y.; Novoselac, A.; Goldstein, A. H.; Lucic, G.; Waring, M. S.; DeCarlo, P. F. Observations and contributions of real-time indoor ammonia concentrations during HOMEChem. Environ. Sci. Technol. 2019, 53, $8591-8598$.

(30) Bai, Z.; Dong, Y.; Wang, Z.; Zhu, T. Emission of ammonia from indoor concrete wall and assessment of human exposure. Environ. Int. 2006, 32, 303-311.

(31) Larson, T.; Covert, D.; Frank, R.; Charlson, R. Ammonia in the human airways: neutralization of inspired acid sulfate aerosols. Science 1977, 197, 161-163.

(32) Nose, K.; Mizuno, T.; Yamane, N.; Kondo, T.; Ohtani, H.; Araki, S.; Tsuda, T. Identification of ammonia in gas emanated from human skin and its correlation with that in blood. Anal. Sci. 2005, 21, $1471-1474$

(33) Turner, C.; Šanner, P.; Smith, D. A longitudinal study of ammonia, acetone and propanol in the exhaled breath of 30 subjects using selected ion flow tube mass spectrometry, SIFT-MS. Physiol. Meas. 2006, 27, 321-337.

(34) Španěl, P.; Dryahina, K.; Smith, D. Acetone, ammonia and hydrogen cyanide in exhaled breath of several volunteers aged 4-83 years. J. Breath Res. 2007, 1, 011001.

(35) Spanel, P.; Dryahina, K.; Smith, D. The concentration distributions of some metabolites in the exhaled breath of young adults. J. Breath Res. 2007, 1, 026001.

(36) Smith, D.; Wang, T.; Pysanenko, A.; Šanane, P. A selected ion flow tube mass spectrometry study of ammonia in mouth- and noseexhaled breath and in the oral cavity. Rapid Commun. Mass Spectrom. 2008, 22, 783-789.

(37) Schmidt, F. M.; Vaittinen, O.; Metsälä, M.; Lehto, M.; Forsblom, C.; Groop, P.-H.; Halonen, L. Ammonia in breath and emitted from skin. J. Breath Res. 2013, 7, 017109.

(38) Chen, W.; Metsälä, M.; Vaittinen, O.; Halonen, L. The origin of mouth-exhaled ammonia. J. Breath Res. 2014, 8, 036003. 
(39) Mochalski, P.; Unterkofler, K.; Teschl, G.; Amann, A. Potential of volatile organic compounds as markers of entrapped humans for use in urban search-and-rescue operations. Trends Anal. Chem. 2015, $68,88-106$.

(40) Furukawa, S.; Sekine, Y.; Kimura, K.; Umezawa, K.; Asai, S.; Miyachi, H. Simultaneous and multi-point measurement of ammonia emanating from human skin surface for the estimation of whole body dermal emission rate. J. Chromatogr. B: Anal. Technol. Biomed. Life Sci. 2017, 1053, 60-64.

(41) Klepeis, N. E.; Nelson, W. C.; Ott, W. R.; Robinson, J. P.; Tsang, A. M.; Switzer, P.; Behar, J. V.; Hern, S. C.; Engelmann, W. H. The National Human Activity Pattern Survey (NHAPS): a resource for assessing exposure to environmental pollutants. J. Expo. Sci. Environ. Epidemiol. 2001, 11, 231.

(42) Bekö, G.; Wargocki, P.; Wang, N.; Li, M.; Weschler, C. J.; Morrison, G.; Langer, S.; Ernle, L.; Licina, D.; Yang, S.; Zannoni, N.; Williams, J., The Indoor Chemical Human Emissions and Reactivity project (ICHEAR): Overview of experimental methodology and preliminary results. Indoor Air, 2020, submitted.

(43) Albrechtsen, O. Twin climatic chambers to study sick and healthy buildings. Proc. Health. Build. 1988, 3, 25-30.

(44) Martin, N. A.; Ferracci, V.; Cassidy, N.; Hoffnagle, J. A. The application of a cavity ring-down spectrometer to measurements of ambient ammonia using traceable primary standard gas mixtures. Appl. Phys. B 2016, 122, 219.

(45) Yver Kwok, C.; Laurent, O.; Guemri, A.; Philippon, C.; Wastine, B.; Rella, C. W.; Vuillemin, C.; Truong, F.; Delmotte, M.; Kazan, $\mathrm{V}$. laboratory and field testing of cavity ring-down spectroscopy analyzers measuring $\mathrm{H}_{2} \mathrm{O}, \mathrm{CO}_{2}, \mathrm{CH}_{4}$ and $\mathrm{CO}$. Atmos. Meas. Tech. 2015, 8, 3867-3892.

(46) Nazaroff, W. W. Inhalation intake fraction of pollutants from episodic indoor emissions. Build. Environ. 2008, 43, 269-277.

(47) Razjouyan, J.; Lee, H.; Gilligan, B.; Lindberg, C.; Nguyen, H.; Canada, K.; Burton, A.; Sharafkhaneh, A.; Srinivasan, K.; Currim, F. for wellbeing: Controlling relative humidity in the workplace matters for our health. Indoor Air 2020, 30, 167-179.

(48) Duncan, S. M.; Tomaz, S.; Morrison, G.; Webb, M.; Atkin, J.; Surratt, J. D.; Turpin, B. J. Dynamics of Residential Water-Soluble Organic Gases: Insights into Sources and Sinks. Environ. Sci. Technol. 2019, 53, 1812-1821.

(49) Asgharzade, S.; Vahedpour, M. Mechanism and thermodynamics of multichannel 1: 1 ammonia and ozone tropospheric oxidation reaction. Prog. React. Kinet. Mech. 2013, 38, 266-282.

(50) Norwood, D. M.; Wainman, T.; Lioy, P. J.; Waldman, J. M. Breath ammonia depletion and its relevance to acidic aerosol exposure studies. Arch. Environ. Health 1992, 47, 309-313.

(51) Sato, K. The physiology, pharmacology, and biochemistry of the eccrine sweat gland. Reviews of Physiology, Biochemistry and Pharmacology; Springer, 1977; pp 51-131.

(52) U.S. EPA. Exposure Factors Handbook 2011 Edition (Final Report), U.S. Environmental Protection Agency: Washington, DC, EPA/600/R-09/052F 2011.

(53) Persily, A.; de Jonge, L. Carbon dioxide generation rates for building occupants. Indoor Air 2017, 27, 868-879.

(54) Sander, R. Compilation of Henry's law constants (version 4.0) for water as solvent. Atmos. Chem. Phys. 2015, 15, 4399-4981.

(55) Zheng, J. Y.; Yin, S. S.; Kang, D. W.; Che, W. W.; Zhong, L. J. Development and uncertainty analysis of a high-resolution $\mathrm{NH}_{3}$ emissions inventory and its implications with precipitation over the Pearl River Delta region, China. Atmos. Chem. Phys. 2012, 12, 70417058. 